\title{
CRITICAL COMPONENTS OF ONLINE LEARNING READINESS AND THEIR RELATIONSHIPS WITH LEARNER ACHIEVEMENT
}

\author{
Dr. Harun CIGDEM \\ Department of Computer Technologies \\ Land Forces Non-Commissioned Officer Vocational College, Balikesir, TURKEY \\ Dr. Mustafa OZTURK \\ School of Foreign Languages \\ Hacettepe University, Ankara, TURKEY
}

\section{ABSTRACT}

This study aimed to examine the relationship between certain factors of online learning readiness and learners' end-of-course achievements. The study was conducted at a twoyear post-secondary Turkish military school within the scope of the course titled Computer Literacy, which was designed and implemented in a blended way. The data were collected from 155 post-secondary military students through an online questionnaire. Three sub-scales of Hung et al.'s Online Learning Readiness Scale were used to collect the data during the first two weeks of the course. Descriptive and inferential statistics, such as Pearson correlation coefficients and linear regression analyses were performed to analyze the data. The descriptive results of the study indicated that students' motivation for online learning was higher than both their computer/Internet self-efficacy and their orientations to self-directed learning. The inferential results revealed that the students' end-of-course grades had significantly positive relationships with their computer/Internet self-efficacy and self-directed learning orientations. Finally, the students' self-direction towards online learning appeared to be the strongest predictor of their achievements within the course; whereas computer/Internet self-efficacy and motivation for learning did not predict the learner achievement significantly.

Keywords: Online learning readiness, learner achievement, blended learning, computer literacy

\section{INTRODUCTION}

In this day and age, technology affects almost every aspect of our lives and continually change the way we learn, teach, and work on the information. With the help of the Internet technologies, e-learning or online learning that makes new instructional practices convenient for students, which was not possible in traditional classroom settings due to time and space constraints, has become a noteworthy method (Cigdem, 2015). Online learning can be described as an action of delivering course materials such as lecture notes, videos, exams, and slides to the learners by devices using Internet technology, although "e-learning", and "distance education" have also been used. Demiray (2011) has emphasized the importance of online learning and online learning tools, for making better learning and teaching in higher education. Online learning has become more and more popular as online technologies and improved educational pedagogy have supplied educators with constantly enlarging opportunities to build high quality, efficient, rigorous, and valuable instructive access to constantly increasing numbers of students. There are many existing online learning tools such as Atutor, Blackboard, Claroline, CanvasLMS and MOODLE that offer many educational tools. 
MOODLE (Modular Object-Oriented Dynamic Learning Environment) is one of the learning management systems (LMSs) which have been used most. MOODLE serves as a free open source platform for LMSs and offers an environment that allows sharing course content to support conventional instruction. It is flexible since it can be accessed anywhere as long as student has a personal device with Internet connection such as smart phone, tablet or computer. In a flexible learning environment, the content of a course is easier to access for learners and learners are able to study at their own speed via the Web, and this plays an important role on their achievement (Chen et al., 2009; Liao, 2007). As a result, educational institutions have assigned great efforts to develop blended learning environments, which stand for the use of key features belonging to face to face and online instructional methods for learners to share and obtain information (Akkoyunlu \& Soylu, 2008; Cigdem \& Topcu, 2013; Lynch \& Dembo, 2004; Osguthorpe \& Graham 2003; Owston, York, \& Murtha, 2013).

Many studies have found the positive results of blended learning, and also a positive impact of blended learning on student achievement has been shown (Lee, Yoon, \& Lee 2009). Escobar-Rodriguez and Mongo-Lozano (2012) claimed that learning-teaching process has become better by using MOODLE. Martín-Blas and Serrano-Fernández (2009) used MOODLE to prepare more interesting activities thus making the learning process friendlier and more interesting for their learners. In the use of MOODLE there are some difficulties appeared as a result of the lack of capabilities and skills for its use, that can reduce these results or even turn down them (Paragia, Paragin, Jipa, Savu, \& Dumitrescu, 2011). Online learning and MOODLE have been established in a number of faculties. Still, many universities fail to take benefits of such attempts and face difficulties in achieving effective strategies, as well as in delivery, efficiency, and acceptance of online courses (Park, 2009; Wang \& Wang, 2009).. Learners are considered to be the most important elements of online learning processes (Aydin \& Tasci, 2005). Learner needs and skills should be central while designing and developing blended courses (Sahin \& Shelley, 2008), when a course become unsuccesful to meet learner hopes and needs it may result with reducing levels of learner participation and motivation (Bradford, 2011) However, one of the key factors shaping the effectiveness of online learning environments is readiness factor (Artino, 2009; Galy, Downey \& Johnson, 2011; Kruger-Ross \& Waters, 2013). Yukselturk (2009) found that online learning readiness was one of the strongest predictors of satisfaction for students in online courses. Online learning readiness plays a significant role to encourage learners to be involved in online learning activities. So readiness for online learning readiness can be perceived as a crucial factor to be taken into account in any development of online learning environments (Ilgaz \& Gulbahar, 2015).

Although research studies in online learning has risen significantly in the last years, much is still unknown regarding factors influencing learner achievement in these online learning environments utilizing LMSs. There are many unanswered questions. One of these questions is which the critical factors affect learner achievement in online mode of blended courses. In this sense, learners' online learning readiness along with online contents must be reviewed carefully in order to improve the quality of those attempts, and schools are to consider improving learners' readiness to use online learning systems more efficiently (Cigdem \& Yildirim, 2014; Wang et al. 2009).

\section{BACKGROUND OF THE STUDY}

Online learning readiness can be described in three major features: choices for online learning as opposed to face-to-face learning instructions; competence and confidence in using the technological tools; and ability to learn seperately (Tang \& Lim, 2013). According to Guglielmino and Guglielmino (2003), online learning readiness can be estimated by evaluating a user's competency in using technological tools (Schreurs, Sammour, \& Ehlers, 2008). Within this framework, McVay (2001) focused on student behaviors and attitudes to determine readiness, and Hung et al. (2010) added some new 
dimensions to the readiness concept such as computer/Internet self-efficacy, learner control, motivation for learning, online communication self-efficacy and self-directed learning.

Bearing in mind that the learners' pre-existing readiness for online learning might influence their cognitions and actions regarding the online mode of blended learning environments, it is essential to understand their online learning readiness. Therefore, in this research, learners' online learning readiness and its effects on blended learning outcomes were investigated. Within this framework, these three major components were discussed and examined in this study: self-directed learning, computer/Internet selfefficacy, and motivation for learning.

To start with the first one, Knowles (1975) defines self-directed learning as "a process in which individuals take the initiative, with or without the help of others, in diagnosing their learning needs, formulating goals, identifying human and material resources, choosing and implementing appropriate learning strategies, and evaluating learning outcomes" (p. 18). In this regard, self-directed learning has been characterized as an active and constructive process by which learners make plans and set objectives prior to learning, monitor their own progress during learning, and subsequently self-evaluate their achievement after learning (Pintrich, 2000; Zimmerman, 2008). According to Zimmerman (2002) self-regulated learning helps students learn more effectively and performance better. Together with the increase in online enrollments, academicians have started to show an interest in students' academic motivation and self-regulation in online courses (Artino, 2008; Dabbagh \& Kitsantas, 2004). Students should manage time and information effectively to be more active and responsible in their learning, complete work on time, and participate in class works in online learning environments (Hung et al., 2010).

Researchers have reached a consensus that students' self-directed learning readiness has been positively associated with students' readiness for online study (Demir Kaymak \& Horzum, 2013) and achievement in online courses (Artino, 2008; 2009a; Lee, Shen, \& Tsai, 2008; Liaw \& Huang, 2013; Paechter, Maier \& Macher, 2010; Pintrich, 2000; Puzziferro, 2008; Wang, Shannon \& Ross, 2013; Yukselturk \& Bulut, 2007). There are also studies disconfirming the significant relationship between academic achievement and self-regulation (Cigdem, 2015; Ergul, 2004).

As for the second component, motivation for learning encompasses learners' all kinds of movements towards and engagements with learning activities. As Wolters (2010) clarifies, the primary factor that facilitates students' persistence in their academic tasks is their motivational beliefs. Motivated learners are attributed to have low latency and high perseverance about task engagement (Artino \& Stephens, 2009), and therefore, their motivational orientation towards a task has significant influences on their performances (Hung et al. 2010) and facilitate their efforts to get higher grades, awards, or prizes (Baeten, et al. 2010; Hung et al. 2010; Saadé, He, \& Kira 2007). Considering this chain, learners' motivational beliefs and self-regulatory behaviors would be related to the nature of an online course and how that course relates to them personally (Artino, 2009b). With the rising of online modes of learning, educators and researchers have come to figure out that self-regulated and highly-motivated learners are most likely to be successful in blended learning. Since online learning appears as a sort of studentcentered environment, highly-motivated students possibly achieve better outcomes (Baeten, Kyndt, Struyven, \& Dochy, 2010).

The last component, self-efficacy is defined as "people's judgments of their capabilities to organize and execute courses of action required to attain designated types of performances" (Bandura 1986, p. 391). In this context, users' beliefs about their abilities to use a technological tool to accomplish a specific task is known to be computer selfefficacy (Compeau \& Higgins, 1995), which operates at two distinct levels: general computing level and specific application level (Yi \& Hwang, 2003) such as the Internet 
use. It is claimed that task-specific self-efficacy might be used as a reliable indicator predicting the task performance (Bandura 1986; Zimmerman 2000). That is why selfefficacy is critical to be identified before starting to implement a new technology. Learners with higher self-efficacy towards learning through online courses are usually considered to be more motivated, more persistent and better achievers in such courses (Ergul, 2004; Linnenbrink \& Pintrich, 2002; Lynch \& Dembo, 2004). Moreover, learners with lower self-efficacy are thought to hold negative perceptions related to requested tasks, consider the tasks not as challenging but threatening and feel confused or even lost when they meet new technologies (Simsek, 2011).

Technical skills including computers and the Internet have a connection with learners' achievement and performance in online learning environments (Hung et al., 2010). Although, learners' self-efficacy regarding online learning is claimed to be a key predictor of their achievement (Cigdem, 2015), some conflicting research indicated that selfefficacy of online technologies was either a poor predictor of success in online courses (DeTure, 2004) or was not correlated with achievement at all (Puzziferro, 2008). Nevertheless, a number of studies emphasized the role of self-efficacy in online learning achievements. For instance, Joo, Bong, and Choi (2000) examined the relationship between self-efficacy and learners' achievement in a web-based instruction and found that technological self-efficacy is a significant variable that determining learners' achievement in distance education. Similarly, Wang and Newlin (2002) concluded that performance in an online course can be predicted from self-efficacy for online technologies. In Lynch and Dembo's (2004) study, self-efficacy, among other factors, was one of two main predictors of learners' performance in a blended learning course. In another study, Bell and Akroyd (2006) found that learners' self-efficacy was one of the primary predictors of achievement.

It is important to determine the factors that affect achievement of learners at blended learning environment. Few studies exist in the literature about the influences of online learning readiness and possible factors that influence the outputs of online learning (Keramati, Afshari-Mofrad \& Kamrani, 2011). Blended Computer Literacy course achievement is based on students' performances. Therefore, this study is conducted to determine the relationship of online learning readiness factors and learners' achievement in blended Computer Literacy course that using MOODLE LMS.

Putting all the critical components portrayed above together, this study aimed to answer the following research questions:

$>$ What are military vocational college students' perceptions about the following dimensions of online learning readiness: (a) computer/internet self-efficacy, (b) self-directed learning, and (c) motivation for learning?

$>$ Is there any significant correlation between learner achievement and the three dimensions (computer/internet self-efficacy, self-directed learning, and motivation for learning)?

$>$ Can learner achievement be predicted from computer/internet self-efficacy, selfdirected learning, and motivation for learning in a blended Computer Literacy course?

\section{METHODOLOGY}

\section{Research Context}

This study was conducted at a two-year post-secondary Turkish military school within the scope of the course titled Computer Literacy, which was designed and implemented in a blended way. Course materials were deployed over the intranet on MOODLE.

Videos related to word processing software and spreadsheet were produced by the lecturer. Students were able to review the videos at anytime and anywhere within the college campus. The course lasted 15 weeks each of which included a 100-minute face-toface session. In each face-to-face session, the content of the week was presented to the 
students and the students were left to practice word processing and spreadsheet activities in computer laboratories. Students were allowed to read the content, download the resources such as lecture notes, videos, slides and journal papers, and follow the instructions to complete activities of the week at anytime they want. Screenshot example of the course website is displayed in Figure 1.

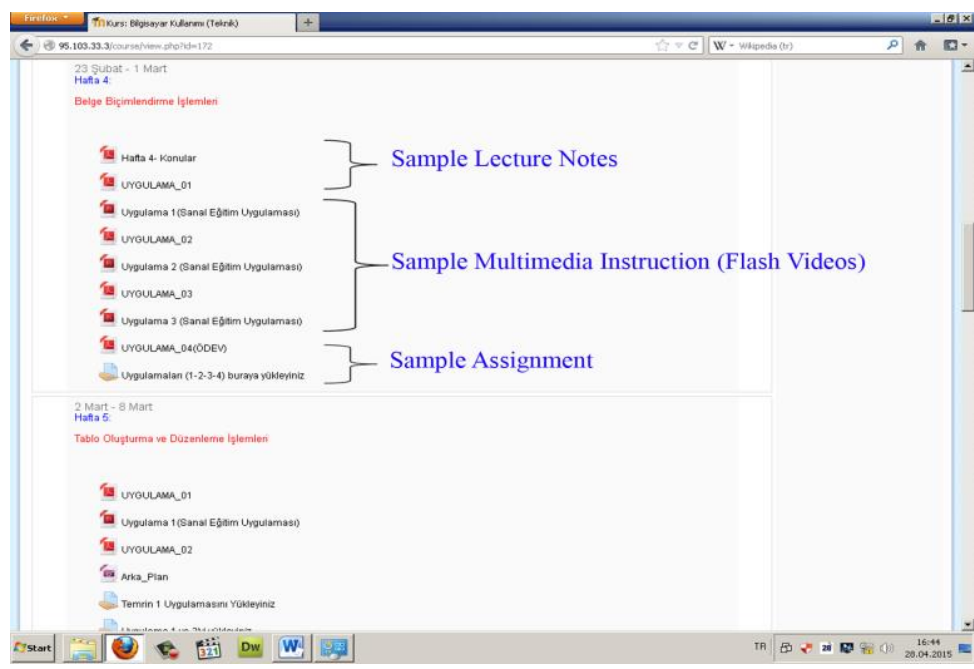

Figure: 1

A Screenshot of Computer Literacy Website

\section{Participants}

As one of the researchers works as an instructor who gives the Computer Literacy course in the research context, convenient sampling strategy was adopted and 155 postsecondary military students were included as the participants of the study. All of the participants were male staying in the college campus as it was a military school. $60 \%$ of them were studying at the department of Electronics and Communication Technologies and the rest $(\mathbf{4 0} \%)$ at the department of Automotive Technologies. A great majority of the participants graduated from vocational high schools $(n=126)$, and the others from general high schools $(n=29)$. Finally, most of the participants did not have a prior experience on web-based education $(n=120)$, while the remains had $(n=35)$. As the study was carried out in a military school with male students, the applicability and generalizability of its findings are limited (see Table 1 for the demographic information of the participants).

Table: 1

Demographics

\begin{tabular}{llcc}
\hline $\begin{array}{l}\text { Background } \\
\text { Dimensions }\end{array}$ & Groups & $n$ & $(\%)$ \\
\hline Academic program & $\begin{array}{l}\text { Automotive Technologies } \\
\text { Electronics and Communication } \\
\text { Technologies }\end{array}$ & 61 & 39.4 \\
& Vocational High School & 94 & 60.6 \\
Type of High School & General School (non-vocational) & 126 & 81.3 \\
& Yes & 29 & 18.7 \\
Owning a computer & No & 121 & 78.1 \\
& & 34 & 21.9 \\
Web-based education & Yes & 35 & 21.9 \\
\hline & No & 120 & 78.1 \\
\hline
\end{tabular}


Data Collection Tools

The data were collected through an online questionnaire consisting of two sections: (a) items to gather demographic information about the participants and (b) items aimed to measure the participants' online learning readiness. The second section included items adopted from Hung et al.'s (2010) Online Learning Readiness Scale (OLRS) which was translated into Turkish by Yurdugul and Alsancak Sarıkaya (2013). Meaningful work on developing and testing online learning readiness scales has been done. Hung et al. (2010) declared a belief that McVay's (2000) questionnaire was without an emphasis on selfdirected learning, motivation for learning, and learner control. So, Hung et al. (2010) advanced their version of the OLRS to include these factors and other factors of computer and Internet self-efficacy and online communication self-efficacy. They tested the internal consistency and construct validity as well as confirming the factor structure. All factors displayed adequate reliability and discriminant validity.

Although the original scale included five dimensions (computer/Internet self-efficacy, self-directed learning, motivation for learning, learner control, and online communication self-efficacy), the first three dimensions were used in the current study with the purpose of measuring military students' readiness for online learning. In order to ensure that the items constitute a reliable scale, reliability analysis was performed for each dimension and Cronbach's alpha levels ranged from .75 to .80 (see Table 2 for the alpha values).

Table: 2

Cronbach's Alpha Coefficients

\begin{tabular}{lcccc}
\hline Dimensions & Items & $\begin{array}{c}\text { Hung et al. } \\
(2010)\end{array}$ & Current Study \\
\hline Computer/Internet & self- & 3 & 0.736 & 0.797 \\
efficacy & 5 & 0.871 & 0.750 \\
Self-directed learning & 4 & 0.843 & 0.771 \\
Motivation for learning & & & \\
\hline
\end{tabular}

\section{RESULTS}

In relation to the first research question investigating whether the participants are ready for online learning, the findings obtained from descriptive analyses indicated that students' motivation for learning $(M=4.15)$ is higher than both their computer selfefficacy $(M=3.55)$ and their self-directed learning inclinations $(M=3.82)$ (see Table 3$)$.

Table: 3

Descriptive Results

\begin{tabular}{lccc}
\hline Dimensions & $N$ & $M$ & $S D$ \\
\hline Computer/Internet self-efficacy & 155 & 3.55 & 1.0 \\
Self-directed learning & 155 & 3.82 & .67 \\
Motivation for learning & 155 & 4.15 & .69 \\
\hline
\end{tabular}

In order to see the correlations between the factors of online learning readiness and the participants' course grades, Pearson correlation coefficients were conducted. At this point, a $p$ value of less than $.008(.05 / 6=.008)$ was required for significance by using the Bonferroni approach to control Type I error across the 6 correlations. The correlational analyses revealed that the participants' course grades had significantly positive relationships with computer/Internet self-efficacy, $r(153)=.21, p<.001$, and selfdirected learning, $r(153)=.32, p<.001$. These findings could mean that as the participants' self-efficacy and self-directed learning orientations tend to increase, their achievements in a blended course would also increase (see Table 4). 
Table: 4

Correlations between Course Grades and Online Readiness Factors

\begin{tabular}{llccc}
\hline \multirow{2}{*}{ Variable } & Dimensions & $\begin{array}{c}\text { Pearson } \\
\text { Corr. }\end{array}$ & $\begin{array}{c}\text { Sig. } \\
(2-t a i l e d)\end{array}$ & $N$ \\
\hline Course Grades & Computer/Internet self-efficacy & .21 & .011 & 155 \\
& Self-Directed Learning & .32 & .001 & 155 \\
& Motivation For Learning & .16 & .050 & 155 \\
\hline
\end{tabular}

As for the third research question, regression analysis conducted to see whether learner achievement was predicted from the factors of online learning readiness put forward a significant result indicating that course grades, which means meeting all the requirements of the course and achieving the tests, were predicted only from the following factor of online learning readiness: self-directed learning, $R^{2}=.104, F(3,151)$ $=5.873, p<.005$ (see Table 5). The findings could mean that it is hard to explain learner achievement through computer/Internet self-efficacy and motivation for learning as they did not seem to be significant predictors of the Computer Literacy course grades of military students. However, students' inclinations towards self-directed learning happened to significantly contribute to students' course grades in the Computer Literacy course, as it appeared as the most important predictor in the current study.

Table: 5

Regression Analysis Results

\begin{tabular}{lccccc}
\hline Variables & $\boldsymbol{B}$ & $\boldsymbol{S E}$ & $\boldsymbol{\beta}$ & $\boldsymbol{t}$ & $\boldsymbol{p}$ \\
\hline Computer/Internet self-efficacy & $\mathbf{1 . 4 0 8}$ & $\mathbf{1 . 6 2 5}$ & .075 & .867 &. $\mathbf{3 8 8}$ \\
Self-directed learning & $\mathbf{8 . 0 3 0}$ & $\mathbf{2 . 7 1 1}$ & .287 & $\mathbf{2 . 9 6 3}$ & .004 \\
Motivation for learning & -.280 & $\mathbf{2 . 4 3 2}$ & -.010 & -.115 & .908 \\
\hline
\end{tabular}

\section{DISCUSSION AND CONCLUSION}

On the basis of the descriptive results of the study, military students seemed to be highly motivated to learn thorough a blended design, as they rated the items pertaining to motivation for learning more positively than the other two dimensions. This finding was consistent with the related literature (Cigdem \& Yildirim, 2014; Hung et al. 2010; Tang \& Lim, 2013) putting forward that students are ready for online learning processes. However, in Hung et al.'s study (2010), the highest ratings were given by the participants to the dimension of computer/Internet self-efficacy. In the current study, it was seen that the participants could carry out their own study plan and have expectations from their learning to some extend. Additionally, they could comfortably use the Internet as well as online learning software. They also seemed to be confident in performing the basic functions of office programs.

In order to design effective blended learning environments, it is crucial to examine what would assist students' learning and achievement as well as the characteristics of successful learners (Yukselturk \& Bulut, 2007). With the purpose of investigating what factors of online learning readiness are able to predict learner achievement in a blended computer literacy course, three dimensions were inquired within the scope this study: self-efficacy, self-directed learning, and motivation factors.

Looking into the correlational analyses between the factors of online learning readiness and learner achievement, it was seen that computer literacy course grades were 
significantly and positively correlated with self-efficacy and self-directed learning factors. As new generations of online learning technologies, such as videos, podcasts, and online quizzes enter educational environments, being ready to use them for learning purposes becomes a valuable skill because it means students can try different tools, and choose which ones fit their needs best.

The results of regression analysis revealed that learner's self-direction was the strongest significant predictor of achievement in the Computer Literacy course. This point is similar to the findings of Artino (2008; 2009), Lee, Shen, and Tsai (2008), Liaw and Huang (2013), Paechter et al. (2010), Pintrich (2000), Puzziferro (2008), Wang, Shannon, and Ross (2013), and Yukselturk and Bulut (2007). In this regard, students with higher levels of self-direction towards the online mode of a blended learning course tend to have better learning achievements. There are also studies (Cigdem, 2015; Ergul, 2004) contradicting with this point as they did not claim learners' self-direction as an important predictor of achievement. As a suggestion, learners might improve self-directed learning skills, especially for online mode of blended learning environment. It is also recommended that learners need full support towards the use of LMS and manage their time for the LMS participation.

Another striking point derived from the regression analysis is that self-efficacy and was not a significant predictor of learners' achievement. This finding justifies DeTure's (2004) and Puzziferro's (2008) studies. As computer and the Internet technologies have been upgraded over time, problems related to the use of such technologies seem to be declining. Because of the continuing spread of technology usage across the educational spectrum, today's students enter colleges with a greater computer experience than their predecessors. This point might be explained through such developments. At the first weeks of the online learning process, learners should have known to how online learning environment suitable their needs and also, they should have learnt what properties it has.

In addition to previous statements, LMS should be well performed and have friendlier use. Also, the network technology is highly important if we implement such systems. If LMS server has a breakdown, this will cause a problem to learner participation in online mode of blended class. This issue will diminish learner motivation on online learning participation. Hence, it will have a direct impact on learner' achievement. Therefore, for future research it should be discussed on usability of LMS and how to improve the implementation of current system in higher education.

\section{BIODATA and CONTACT ADDRESSES of the AUTHORS}

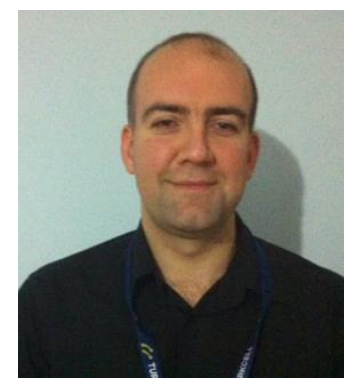

Dr. Harun CIGDEM holds a bachelor's degree in Computer Education and Instructional Technologies and a master's degree in Educational Sciences from Uludag University. He received his PhD in Computer Education and Instructional Technologies from Anadolu University in 2012. He is the administrator of Course Portal of Non-Commisioned Officer Vocational College. He teaches operating systems, computer networks, and system and network administration courses in the college. His research interests involve instructional design, elearning, e-assessment and self-regulation.

Harun CIGDEM, Ph.D.

Turkis Land Forces Noncommissioned Officer School

Department of Computer Technologies

Cayirhisar, Balıkesir, TURKEY

Phone: +902662212350; +90 5333151600

Email: hcigdem@gmail.com 


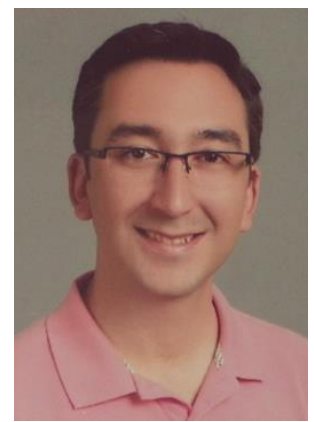

Dr. Mustafa OZTURK holds a bachelor's degree in Foreign Language Education and a master's degree in Educational Sciences from Middle East Technical University. In 2007, he completed a non-degree postgraduate study in Learning, Learning Environments and Educational Systems in University of Turku, Finland. He received his PhD in Curriculum and Instruction from Middle East Technical University in 2014. He is currently conducting a postdoctoral research at Columbia University Teachers College. His research interests lie in the areas of curriculum studies, teacher education, language teaching, instructional design, e-learning, and education for sustainable development.

Mustafa OZTURK, Ph.D.

Hacettepe University, School of Foreign Languages, Department of Basic English

Beytepe Campus, Cankaya, Ankara, TURKEY

Phone: +903122978085

Fax: +903122992158

Email: mustafaozturk@hacettepe.edu.tr

\section{REFERENCES}

Akkoyunlu, B., \& Soylu, M. Y. (2008). A study of student's perceptions in a blended learning environment based on different learning styles. Educational Technology \& Society, $11(1)$, 183-193.

Artino, A. R. (2008). Motivational beliefs and perceptions of instructional quality: Predicting satisfaction with online training. Journal of Computer Assisted Learning, 24, 260-270

Artino, A. R. (2009a). Online learning: Are subjective perceptions of instructional context related to academic success? Internet and Higher Education, 12, 117-125.

Artino, A.R. (2009b). Think, feel, act: motivational and emotional influences on military students' online academic success. J Comput High Educ

Artino, A. R., Jr., \& Stephens, J. M. (2009). Beyond grades in online learning: Adaptive profiles of academic self-regulation among Naval Academy undergraduates. Journal of Advanced Academics, 20(4), 568-601.

Aydin, C. H. \& Tasci, D. (2005). Measuring readiness for e-Learning: Reflections from an emerging country. Educational Technology \& Society, 8 (4), 244-257.

Baeten, M., Kyndt, E., Struyven, K. \& Dochy, F. (2010). Using student-centred learning environments to stimulate deep approaches to learning: factors encouraging or discouraging their effectiveness. Educational Research Review, 5(3), 243-260.

Bandura, A. (1986). Social foundations of thought and action; a social cognitive theory. Prentice Hall. Eaglewood Cliffs. NJ.

Bell, P. D., \& Akroyd, D. (2006). Can factors related to self-regulated learning predict learning achievement in undergraduate asynchronous Web-based courses? International Journal of Instructional Technology and Distance Learning, 3(10), 516.

Bradford, G. R. (2011). A relationship study of student satisfaction with learning online and cognitive load: Initial results. Internet and Higher Education, 14(4), 217-226.

Chen, S. W., Stocker, J., Wang, R. H., Chung, Y. C. \& Chen, M. F. (2009). Evaluation of selfregulatory online learning in a blended course for post-registration nursing students in Taiwan. Nurse Education Today, 29 (2009), 704-709.

Cigdem, H. (2015). How does self-regulation affect computer-programming achievement in a blended context? Contemporary Educational Technology, $6(1), 19-37$ 
Cigdem, H. \& Topcu, A. (2013). Students' perception of e-learning in the technical vocational school. Science Journal of Turkish Military Academy, 23(2), 1-19.

Cigdem, H. \& Yildirim, O.G. (2014). Effects of students' characteristics on online learning readiness: a vocational college example. Turkish Online Journal of Distance Education-TOJDE, 15(3), 80-93.

Compeau, D. R., \& Higgins, C. A. (1995). Computer self-efficacy: development of a measure initial test. MIS Quarterly, 19(2), 189-211.

Dabbagh, N., \& Kitsantas, A. (2004). Supporting self-regulation in student-centered webbased learning environments. International Journal on E-Learning, 3(1), 40-47.

Demir Kaymak, Z.\& Horzum, M. B. (2013). Relationship between online learning readiness and structure and interaction of online learning students. Educational Sciences: Theory and Practice 13 (3), $1792-1797$.

Demiray, U. (2011). Distance education and eLearning practices: In Turkey and Eastern countries. eLearning Papers, No. 24, April. Retrieved from http://www.openeducationeuropa.eu/hu/download/file/fid/22301

DeTure, M. (2004). Cognitive style and self-efficacy: Predicting student success in online distance education. American Journal of Distance Education, 18(1), 21-38.

Ergul , H. (2004). Relationship between student characteristics and academic achievement in distance education and application on students of Anadolu University. Turkish Online Journal of Distance Education-TOJDE, 5(2).

Escobar-Rodriguez, T., \& Monge-Lozano, P. (2012). The acceptance of Moodle technology by business administration students. Computers \& Education, 58, 1085-1093.

Galy, E., Downey, C., \& Jhonson, J. (2011). The effect of using e-learning tools in online and campus-based classrooms on student performance. Journal of Information Technology Education, 10, 209-230.

Guglielmino, P. \& Guglielmino, L. (2003). Are your learners ready for e-learning? In G. Piskurich (Ed.), The AMA handbook of e-learning. New York: American Management Association.

Hung, M., Chou, C., Chen, C. \& Own, Z. (2010). Learner readiness for online learning: Scale development and student perceptions. Computers \& Education, 55, 10801090.

Ilgaz, H. \& Gulbahar, Y. (2015). A Snapshot of Online Learners: e-Readiness, eSatisfaction and Expectations. International Review of Research in Open and Distributed Learning, 16 (2), 171-187.

Joo, Y., M. Bong, and H. Choi. 2000. Self-efficacy for self-regulated learning, academic self-efficacy, and Internet self-efficacy in Web-based instruction. Educational Technology Research and Development 48 (2), 5-17.

Keramati, A., Afshari-Mofrad, M. \& Kamrani, A. (2011). The role of readiness factors in elearning outcomes: An empirical study. Computers \& Education, 57(3), 1919-1929.

Knowles, M. (1975). Self-directed learning: A guide for learners and teachers. New York: Association Press.

Kruger-Ross, M.J. \& Waters, R.D. (2013). Predicting online learning success: Applying the situational theory of publics to the virtual classroom. Computers \& Education, 53, 761-774.

Lee, B. C., J. O. Yoon, \& I. Lee. 2009. "Learners' Acceptance of E-Learning in South Korea: Theories and Results." Computers and Education 53: 13201329.

Lee, T.H., Shen, P.D., \& Tsai, C.W. (2010). Enhance students' computing skills via webmediated self-regulated learning with feedback in blended environment. International Journal of Technology and Human Interaction, 6(1), 15-32. 
Liao, Y. K. C. (2007). Effects of computer-assisted instruction on students' achievement in Taiwan: a meta-analysis. Computers \& Education 48, 216-233.

Liaw, S. S. \& Huang, H.M. (2013). Perceived satisfaction, perceived usefulness and interactive learning environments as predictors to self-regulation in e-learning environments. Computers \& Education 60 (2013), 14-24.

Linnenbrink, E. A. \& Pintrich, P. R. (2002). Motivation as an enabler for academic success. The School Psychology Review 31(3), 313 - 327.

Lynch, R. \& Dembo, M. (2004). Online learning in a blended learning context. International Review of Research in Open and Distance Learning, 5(2), Retrieved February 25, 2014 from http://www.irrodl.org/index.php/irrodl/article/view/189/271

Martín-Blas, T., \& Serrano-Fernández, A. (2009). The role of new technologies in the learning process: Moodle as a teaching tool in Physics. Computers \& Education, 52, 35-44.

McVay, M. (2001). How to be a successful distance learning student: Learning on the Internet. New York: Prentice Hall.

Osguthorpe, R. T., \& Graham, C. R. (2003). Blended learning systems: Definitions and directions. Quarterly Review of Distance Education, 4(3), 227-234.

Owston, R., York, D., \& Murtha, S. (2013). Student perceptions and achievement in a university blended learning strategic initiative. Internet and Higher Education, 18, 38-46.

Paechter, M., Maier, B., \& Macher, D. (2010). Students' expectations of and experiences in e-learning: Their relation to learning achievements and course satisfaction. Computers \& Education, 54(1), 222-229.

Paragia, F., Paragin, S., Jipa, A., Savu, T., \& Dumitrescu, A. (2011). The benefits of using MOODLE in teacher training in Romania. Procedia Social and Behavioural Sciences, 15, 1135-1139.

Park, S. Y. (2009). An analysis of the technology acceptance model in understanding university students' behavioral intention to use e-learning. Educational Technology \& Society, 12(3), 150-162.

Pintrich, P. R. (2000). A motivational science perspective on the role of student motivation in learning and teaching contexts. Journal of Educational Psychology, 95, 667-686.

Puzziferro, M. (2008). Online technologies self-efficacy and self-regulated learning as predictors of final grade and satisfaction in college-level online courses. American Journal of Distance Education, 22(2), 72-89.

Saadé, R. G., He, X. \& Kira, D. (2007). Exploring dimensions to online learning. Computers in Human Behavior, 23(4), 1721-1739.

Sahin, I., \& Shelley, M. (2008). Considering students' perceptions: The distance education student satisfaction model. Educational Technology \& Society, 11(3), 216-223.

Schreurs, J., Sammour, G. \& Ehlers, U. (2008). E-learning Readiness Analysis (ERA): an ehealth case study of e-learning Readiness. Int. J. Knowledge and Learning, 4 (5), 496-508.

Simsek, A. (2011). The relationship between computer anxiety and computer selfefficacy. Contemporary Educational Technology, 2(3), 177-187.

Tang, S. F. \& Lim, C. L. (2013). Undergraduate students' readiness in e-learning: a study at the business school in a Malaysian private university. International Journal of Management \& Information Technology, 4 (2). 198-204. 
Wang, A.T. \& Newlin, M.H. (2002). Online lectures: Benefits for the virtual classroom. THE Journal, 29, 17-22.

Wang, C., Shannon, D., \& Ross, M. (2013). Students' Characteristics, Self-Regulated Learning, Technology, Self-Efficacy, and Course Outcomes in Online Learning. Distance Education, 34(3), 302-323.

Wang, W.-T. \& Wang, C.-C. (2009). An empirical study of instructor adoption of webbased learning systems. Computers \& Education, 53, 761-774.

Wang, Q., Zhu, Z., Chen, L. \& Yan, H. (2009). E-Learning in China. Campus-Wide Information Systems, 26, 47-61.

Wolters, C. A. (2010). Self-regulated learning and the 21st century competencies. Retrieved from:

http://www.hewlett.org/uploads/Self Regulated Learning 21st Century Compe tencies.pdf

Yi, M., \& Hwang, Y. (2003). Predicting the use of web-based information systems: Selfefficacy, enjoyment, learning goal orientation, and the technology acceptance model. International Journal of Human-Computer Studies, 59, 431-449.

Yukselturk, E. \& Bulut, S. (2007). Predictors for Student Success in an Online Course. Educational Technology \& Society, 10(2), 71-83.

Yurdugül, H. \& Alsancak Sarıkaya, D. (2013). The scale of online learning readiness: a study of validity and reliability. Education and Science, 38 (169), 391-406

Zimmerman, B. J. (2000). Self-efficacy: An essential motive to learn. Contemporary Educational Psychology, 25, 82-91.

Zimmerman, B. J. (2002). Becoming a self-regulated learner: An overview. Theory into Practice, 41(2), 64-70.

Zimmerman, B. J. (2008). Investigating self-regulation and motivation: historical background, methodological developments, and future prospects. American Educational Research Journal, 45 (1), 166-183 